\title{
Kajian Hukum Pembentukan Tenaga Ahli Kepala Daerah dalam Sistem Ketatanegaraan Indonesia
}

\author{
Helmy Boemiya \\ Fakultas Hukum Universitas Trunojoyo Madura \\ E-mail : helmy.boemiya@trunojoyo.ac.id \\ Naskah diterima 10 Februari 2020, Revisi 15 April 2020, Terbit 19 April 2020
}

\begin{abstract}
Abstrak
DOI: doi.org/10.21107/pamator.v13i1.6922

Pembentukan tenaga ahli kepala daerah banyak dilakukan oleh kepala daerah dalam menjalankan pemerintahan daerah, namun aturan konkrit secara yuridis dalam konstitusi dan undang-undang tidak ada kejelasan mengatur perihal tersebut. Pengaturan yang ada ialah mengatur mengenai tenaga ahli bagi DPRD dan staf ahli bagi kepala daerah. Permasalahan utama dalam penuisan ini ialah apakah diperbolehkan membentuk tenaga ahli bagi kepala daerah dan bagaimana kajian hukumnya terkait persoalan tersebut. Dalam perspektif hukum tata negara dan hukum administrasi negara terdapat asas freis ermessen atau kebebasan bertindak bagi seorang pejabat negara untuk menjalankan tugasnya. Pembentukan tenaga ahli kepala daerah dapat dilakukan jika berdasar beberapa hal, yaitu berdasarkan konstitusi, perundang-undangan, doktrin hukum dan praktik ketatanegaraan penyelenggaraan pemerintahan daerah di Indonesia selama ini. Maka, Pembentukan tenaga ahli untuk membantu seorang kepala daerah, dalam hal ini kepala daerah dalam sistem ketatanegaraan di Indonesia diperbolehkan sepanjang demi kepentingan umum dan mensejahterakan masayrakat daerah serta tidak bertentangan hukum yang lebih itnggi. Selain itu, tujuan utamanya adalah untuk mensejahterakan masyarakat, maka negara pada konteks ini pemerintah daerah yang ada di Indonesia harus ikut terlibat aktif dalam urusan masyarakat khususnya dalam mensejahterakan masyarakatnya.
\end{abstract}

Kata Kunci : tenaga ahli, kepala daerah, pemerintahan daerah di Indonesia

\section{PENDAHULUAN}

Hubungan Pemerintah Pusat dengan Daerah dapat dirunut dari alinea ketiga dan keempat Pembukaan Undang-Undang Dasar Negara Republik Indonesia Tahun 1945. Alinea ketiga memuat pernyataan kemerdekaan bangsa Indonesia. Sedangkan alinea keempat memuat pernyataan bahwa setelah menyatakan kemerdekaan, yang pertama kali dibentuk adalah Pemerintah Negara Indonesia yaitu Pemerintah Nasional yang bertanggung jawab mengatur dan mengurus bangsa Indonesia. Lebih lanjut dinyatakan bahwa tugas Pemerintah Negara Indonesia adalah melindungi seluruh bangsa dan tumpah darah Indonesia, memajukan kesejahteraan umum dan mencerdaskan kehidupan bangsa serta ikut memelihara ketertiban dunia berdasarkan kemerdekaan, perdamaian abadi, dan keadilan sosial.

Beberapa pemerintah daerah membentuk tenaga ahli dengan tujuan membantu tugas kepala daerah dan melakukan percepatan pembangunan di daerahnya guna mensejahterakan masyarakat daerahnya. Hal ini dilakukan sebagai wujud menjawab tantangan jaman, utamanya revolusi industri 4.0., beberapa daerah telah menerapkan sejak lama terkait tenaga ahli untuk membantu kepala daerahnya, di antaranya terdapat Kota Yogyakarta sudah sejak 2004 menerapkan tenaga ahli untuk membantu walikota Yogyakarta, bahkan beberapa kebijakan strategis merupakan masukan dan rekomendasi dari para tenaga ahli sesuai bidang keahliannya. Pemerintah daerah lainnya yang menerapkan hal serupa ialah Kabupaten Jombang dan Kabupaten Bantul.

Terkait pengaturan tenaga ahli seorang kepala daerah tersebut, tidak terdapat aturan yang mengikat secara jelas dan pasti mengatur perihal tenaga ahli kepala daerah, baik dalam Undang-Undang (UU) Pemerintahan Daerah dan UU Perangkat Daerah maupun peraturan perundangundangan lainnya. Oleh karena itu, berdasarkan UU No. 30 Tahun 2014 diperbolehkan suatu tindakan bebas (kebebasan bertindak) dilakukan oleh 
pejabat yang berwenang untuk melakukan diskresi berdasar persyaratan tertentu, salah satunya AUPB, tidak bertentangan dengan peraturan yang lebih tinggi dan demi kepentingn umum. Hal ini merupakan wujud penerapan welfare state dan freisermessen dalam teori hukum administrasi negara dan tata negara. Menarik untuk dikaji ialah apakah membentuk tenaga ahli kepala daerah di Indonesia diperbolehkan, bagaimana kajian hukum atas perihal tersebut.

\section{PEMBAHASAN}

\section{Beberapa Definisi Tenaga Ahli Dalam Peraturan Perundang-Undangan di Indonesia}

a. Menurut UU No. 7 Tahun 2014 tentang Majelis Permusyawaratan Rakyat, Dewan Perwakilan Rakyat, Dewan Perwakilan Daerah, dan Dewan Perwakilan Rakyat Daerah. (UU MD3)

Frase tenaga ahli ditemukan dalam beberapa pasal, salah satunya terdapat dalam Pasal 417 yang menyatakan bahwa:

(1) Tenaga ahli alat kelengkapan DPR, tenaga ahli anggota DPR, dan tenaga ahli fraksi adalah tenaga yang memiliki keahlian tertentu yang dibutuhkan dalam pelaksanaan tugas dan fungsi alat kelengkapan DPR, anggota dan fraksi.

(2) Dalam satu kali periode masa bakti DPR terdapat paling sedikit 1 (satu) kali kenaikan honorarium tenaga ahli dan staf administrasi anggota DPR sesuai dengan ketentuan peraturan perundangundangan.

(3) Rekrutmen tenaga ahli sebagaimana dimaksud pada ayat (1) dilakukan oleh alat kelengkapan DPR, anggota dan fraksi yang dalam pelaksanaannya dibantu oleh Sekretaris Jenderal DPR.

Berdasarkan pemaparan di atas, yang dimaksud tenaga ahli ialah yang memiliki keahlian tertentu dalam membantu tugas fraksi dan alat kelengkapan DPR. Sehingga pemaknaan tenaga ahli di sini, secara jelas diperuntukkan untuk membantu anggota DPR atau sebagai tenaga ahli DPR.

\section{b. Menurut UU No. 23 Tahun 2014 tentang Pemerintahan Daerah \\ Frase tenaga ahli ditemukan di beberapa pasal, yaitu : Pasal 109 ayat (10)}

menyatakan Sekretariat DPRD Provinsi menyediakan sarana, anggaran, dan tenaga ahli guna kelancaran pelaksanaan tugas fraksi sesuai dengan kebutuhan dan dengan memperhatikan kemampuan APBD. Pasal 162 ayat (10) Sekretariat DPRD Kabupaten/Kota menyediakan sarana, anggaran, dan tenaga ahli guna kelancaran pelaksanaan tugas fraksi sesuai dengan kebutuhan dan dengan memperhatikan kemampuan APBD. Pasal 215 ayat (2) huruf d, menyediakan dan mengoordinasikan tenaga ahli yang diperlukan oleh DPRD dalam melaksanakan fungsinya sesuai dengan kebutuhan. Pasal 397 menyatakan Sekretariat dewan pertimbangan otonomi daerah sebagaiamana dimaksud pada ayat (2) dibantu oleh tenaga ahli.

Berdasarkan pemaparan di atas, tenaga ahli yang dimaksud ialah tenaga ahli DPRD untuk memperlancar tugas dan fungsi fraksi yang ada dalam DPRD. Serta tenaga ahli dewan pertimbangan otonomi daerah. Dalam UU Pemda ini tidak ada penjelasan terkait tenaga ahli kepala daerah.

c. Menurut Peraturan Pemerintah Nomor 18 Tahun 2016 tentang Perangkat Daerah

Frase dan pengaturan tenaga ahli ditemukan dalam beberapa pasal, yaitu : Pasal 9 ayat (4), (5) terkait tugas dari sekretariat DPRD dalam menyediakan dan mengkoordinasikan tenaga ahli yang diperlukan DPRD. Sementara terkait frase staf ahli terdapat Bab tersendiri. Tepatnya dalam Pasal 102 dan 103. Pasal 102 menyatakan bahwa :

(1) Gubernur dan bupati/wali kota dalam melaksanakan tugasnya dapat dibantu staf ahli.

(2) Staf ahli berada di bawah dan bertanggungjawab kepada gubernur atau bupati/wali kota dan secara administratif dikoordinasikan oleh sekretaris Daerah.

(3) Staf ahli sebagaimana dimaksud pada ayat (1) berjumlah paling banyak 3 (tiga) staf ahli.

(4) Staf ahli gubernur dan bupati/wali kota diangkat dari pegawai negeri sipil yang memenuhi persyaratan.

(5) Pengangkatan dan pemberhentian staf ahli gubernur oleh gubernur dan staf ahli bupati/wali kota oleh bupati/wali kota. 
Pasal 103 menyatakan :

(1) Staf ahli sebagaimana dimaksud dalam Pasal 102 bertugas rekomendasi terhadap isu-isu strategis kepada gubernur atau bupati/wali kota sesuai keahliannya.

(2) Untuk membantu pelaksanaan tugas dan fungsi staf ahli gubernur dan staf ahli bupati/wali kota, dapat dibentuk 1 (satu) subbagian tata usaha pada bagian yang membidangi urusan umum/tata usaha.

Berdasarkan pemaparan di atas, dapat dibedakan antara tenaga ahli dan staf ahli. Tenaga ahli yang dimaksud sama maknanya dengan yang diatur dalam UU MD3 dan UU Pemda yaitu terkait tenaga ahli DPRD untuk membantu tugas dan fungsi fraksi atau anggota dewan. Sedangkan staf ahli dalam PP tentang Perangkat Daerah ialah perangkat daerah yang berasal dari pegawai negeri sipil (PNS) yang telah memenuhi persyaratan untuk membantu tugas gubernur/walikota/bupati.

\section{d. Peraturan Walikota Nomor 2 Tahun 2018 tentang Tenaga Ahli Walikota Yogyakarta \\ Menurut Perwali Yogyakarta, tenaga ahli} ialah orang yang mempunyai keahlian bidang tertentu yang membantu melaksanakan tugas-tugas walikota dalam mewujudkan misi pembangunan dalam RPJMD Tahun 2017-2022 sesuai bidang keahliannya.

\section{e. Peraturan Bupati Nomor 31 Tahun 2018 tentang Tenaga Ahli Bupati Jombang}

Menurut Perbup Jombang definisi tenaga ahli ialah tenaga ahli/akademisi yang mempunyai keahlian dibidang tertentu, yang ditugaskan untuk membantu dan memberikan saran pertimbangan kepada Bupati.

f. Peraturan Bupati Nomor 25 Tahun 2016 tentang Pedoman Pengangkatan dan Pemberhentian Tenaga Ahli Bupati

Definisi tenaga ahli dalam perbup tersebut ialah tenaga yang memiliki keahlian di bidang tertentu, yang ditugaskan untuk membantu dan memberikan saran pertimbangan kepada Bupati atau Wakil Bupati. Berdasarkan pemaparan beberapa definisi terkait tenaga ahli di atas, dapat disimpulkan yang dimaksud tenaga ahli kepala daerah (walikota/bupati), pertama, orang yang memiliki keahlian di bidang tertentu. Kedua, bertugas membantu (walikota/bupati). Ketiga, memberi masukan, saran dan pertimbangan kepada walikota/bupati. Oleh karena itu, dalam penulisan ini dibatasi bahwa yang dimaksud dengan tenaga ahli ialah orang yang mempunyai keahlian bidang tertentu, tidak berasal dari pegawai negeri sipil dalam lingkup pemerintah daerah dan ditugaskan untuk membantu kepala daerah dalam menjalankan tugas, sesuai visi dan misi yang tertuang dalam RPJMD.

\section{Kajian Hukum Pembentukan Tenaga Ahli Kepala Daerah di Indonesia}

\section{a. Berdasarkan Landasan konstitusional}

Terkait pemerintahan daerah di atur dalam Pasal 18, 18A dan 18B. Dalam Pasal 18 ayat (5) pemerintahan daerah menjalankan otonomi seluas-luasnya, kecuali urusan pemerintahan yang oleh undang-undang ditentukan sebagai urusan pemerintah pusat. Pasal 18 (6) menyatakan pemerintahan daerah berhak menetapkan peraturan daerah dan peraturan-peraturan lain untuk melaksanakan otonomi dan tugas pembantuan. Kemudian pada Pasal (7) susunan dan tata cara penyelenggaraan pemerintahan daerah di atur dalam undangundang. Berdasarkan pemaparan di atas, dapat disimpulkan bahwa pengaturan pemerintahan daerah diatur lebih lanjut dalam peraturan daerah atau peraturan lainnya dalam melaksanakan otonomi daerah. Terkait tenaga ahli kepala daerah (Walikota/Bupati) memiliki landasan konstitusional guna memajukan kesejahteraan umum, dan daerah memiliki otonomi untuk mengatur dirinya sendiri. Hal ini sesuai prinsip otonomi luas, kecuali beberapa urusan yang telah terbagi antara pemerintah pusat dan pemerintahan daerah.

\section{b.Berdasarkan Peraturan Perundang- Undangan}

Asas dalam penyelenggaran daerah termaktub dalam Pasal 58, terdiri atas : a.Kepastian hukum; b.Tertib penyelenggara negara; c.Kepentingan umum; $d$. Keterbukaan; e.Proporsionalitas; f. Profesionalitas; g.Akuntabilitas; h.Efisiensi; i. Efektivitas; dan j.Keadilan. Pada 
penyelenggaraan pemerintahan daerah dipimpin oleh kepala daerah dan wakil kepala daerah. Tugas dan wewenang kepala daerah termaktub dalam beberapa pasal. Kepala daerah mempunyai tugas :

a. Memimpin pelaksanaan Urusan Pemerintahan yang menjad kewenangan Daerah berdasarkan ketentuan peraturan perundangundangan dan kebijakan yang ditetapkan bersama DPRD;

b. Memelihara ketenteraman dan ketertiban masyarakat;

c. Menyusun dan mengajukan rancangan Perda tentang RPJPD dan rancangan Perda tentang RPJMD kepada DPRD untuk dibahas bersama DPRD, serta menyusun dan menetapkan RKPD;

d. Menyusun dan mengajukan rancangan Perda tentang APBD, rancangan Perda tentang perubahan APBD, dan rancangan Perda tentang pertanggungjawaban pelaksanaan APBD kepada DPRD untuk dibahas bersama;

e. Mewakili daerahnya di dalam dan di luar pengadilan, dan dapat menunjuk kuasa hukum untuk mewakilinya sesuai dengan ketentuan peraturan perundangundangan;

f. Mengusulkan pengangkatan wakil kepala daerah; dan melaksanakan tugas lain sesuai dengan ketentuan peraturan perundang-undangan

Wewenang kepala daerah :

a. Mengajukan rancangan perda

b. Menetapkan Perda yang telah mendapatkan persetujuan bersama DPRD

C. Menetapkan perkada dan keputusan kepala daerah

d. Mengambil tindakan tertentu dalam keadaan mendesak yang sangat dibutuhkan oleh Daerah dan/atau masyarakat

e. Melaksanakan wewenang lain sesuai dengan ketentuan peraturan perundangundangan.

Berdasarkan pemaparan di atas, dapat disimpulkan bahwa kepala daerah selaku pemimpin daerah memiliki tugas yang berat dan membutuhkan bantuan dari sumber daya manusia yang memiliki keahilian guna membantu tugas dan wewenang yang di miliki, serta mewujudkan kesejahteraan masyarakat daerah dan visi-misi kepala daerah itu sendiri. Berkaitan dengan gagasan pembentukan tenaga ahli untuk kepala daerah, kepala daerah memiliki kewenangan dalam menetapkan peraturan kepala daerah dan keputusan kepala daerah, serta mengambil tindakan tertentu guna kebutuhan daerah dan masyarakat daerahnya. Dalam UU Nomor 30 Tahun 2014, Terdapat pengaturan tentang diskresi sebagai sarana untuk melakukan suatu tindakan hukum. Menurut Pasal 1 angka 9, menyatakan bahwa diskresi adalah Keputusan dan/atau tindakan yang ditetapkan dan/atau dilakukan oleh pejabat pemerintahan untuk mengatasi persoalan kongkrit yang dihadapi dalam penyelenggaraan pemerintahan dalam hal peraturan perundang-undangan yang memberikan pilihan, tidak mengatur, tidak lengkap atau tidak jelas, dan/atau adanya stagnasi pemerintahan.

Diskresi hanya dapat dilakukan oleh pejabat pemerintahan yang berwenang, guna bertujuan untuk :
a. Melancarkan pemerintahan;
penyelenggaraan

b. Mengisi kekosongan hukum;

c. Memberi kepastian hukum;

d. Mengatasi stagnasi pemerintahan dalam keadaan tertentu guna kemanfaatan dan kepentingan umum.

Kemudian pengaturan selanjutnya terkait persyaratan diskresi terdapat pada Pasal 24. Pasal tersebut menyatakan bahwa pejabat pemerintahan yang menggunakan diskresi harus memenuhi syarat:

a. Sesuai dengan tujuan diskresi sebagaimana dimaksud dalam Pasal 22 ayat (2);

b. Tidak bertentangan dengan ketentuan peraturan perundang-undangan;

c. Sesuai dengan AUPB;

d. Berdasarkan alasan-alasan yang objektif;

e. Tidak menimbulkan konflik kepentingan dan;

f. Dilakukan dengan itikad baik.

Berdasarkan pemaparan di atas, dapat disimpulkan terdapat pengaturan secara jelas terkait diskresi yang dapat dilakukan oleh pejabat pemerintah dalam hal ini kepala daerah untuk menjalankan roda pemerintahan dalam rangka mewujudkan tujuan daerahnya. Seorang kepala daerah 
dapat membuat peraturan kebijakan terkait hal-hal tertentu yang tidak ada kejelasan aturan, untuk memenuhi hal tersebut harus sesuai dengan peraturan perundang-undang terkait diskresi. Hal utama ialah tidak bertentangan dengan aturan yang lebih tinggi, sesuai dengan AUPB dan demi kepentingan umum, yaitu kepentingan masyarakat daerahnya.

Kajian Teoritis Pembentukan Tenaga Ahli Kepala Daerah dalam Ketatanegaraan Indonesia

\section{a. Berdasarkan Konsepsi Negara Hukum dan Kesejahteraan}

Negara hukum hakikatnya adalah negara yang menolak melepaskan kekuasaan tanpa kendali. Negara yang pola hidupnya berdasarkan hukum yang adil dan demokrasi. Kekuasaan negara harus tunduk pada aturan main. Oleh karena itu, Indonesia sebagai negara hukum telah jelas termaktub pada Pasal 1 ayat (3) UUD NRI Tahun 1945. Dapat diartikan bahwa segala tindakan penyelenggaraan negara di Indonesia harus sesuai hukum yang berlaku atau berdasar atas hukum.

Welfare state adalah suatu konsep negara modern yang bertitik tolak pada negara kesejahteraan. Dimana dalam konsep welfare state negara bukan lagi menjadi negara penjaga malam saja, artinya negara tidak hanya menciptakan keamanan dan ketertiban bagi warganya, melainkan ikut dan turut serta menjamin kesejahteraan warganya. Konsep welfare state dapat dilihat pada sila ke 5 Pancasila, keadilan sosial bagi seluruh rakyat Indonesia, kemudian pada pembukaan alinea ke-empat UUD NRI Tahun 1945 memajukan kesejahteraan umum sebagai tujuan negara, dan contoh konkrit ialah jaminan sosial dan kesehatan yang diatur dalam Pasal 34 UUD NRI Tahun 1945.

Tipe utama negara hukum kesejahteraan adalah adanya kewajiban pemerintah untuk melakukan bestuuruzorg atau pelayanan publik, yakni penyelenggaraan kepentingan umum. Pemerintah diberi kewenangan yang luas untuk melepaskan diri dari hukum formal yang kaku, sehingga dapat melakukan aktivitasnya dengan leluasa. Pemberian kewenangan yang luas dan kemudian di kenal dengan ajaran freisermessen atau pouvoir discretionare, yang secara sederhana dapat dirumuskan sebagai "kemerdekaan pemerintah untuk dapat bertindak atas inisiatif sendiri dalam menyelesaikan persoalan-persoalan sosial" (Marbun dan Mahfud, 1998).

Tujuan utama dari negara yang sedang berkembang adalah perwujudan kesejahteraan masyarakat yang merata. negara yang demikian, dalam teori kenegaraan di sebut sebagai negara yang bertipe kesejahteraan (welfare state type), karena titik beratnya adalah pemerataan kesejahteraan dalam kehidupan masyarakat. Oleh karena itu, negara dituntut untuk berperan aktif dalam menciptakan kesejahteraan, misalnya dengan pengaturan lewat perijinan, penciptaan, kebijaksanaan lewat diregulasi dalam bidang tertentu (Muchsan, 2000).

Berdasarkan pemaparan di atas, dapat disimpulkan bahwa suatu negara hukum yang berkonsep welfare state harus bersandar pada aturan atau undang-undang untuk mewujudkan tujuan negaranya. Oleh karena itu, dalam rencana penyusunan suatu aturan terkait tenaga ahli kepala daerah harus sesuai dengan peraturan yang ada dan tidak bertentangan dengan peraturan yang lebih tinggi. Kemudian hal utama yang harus dilakukan ialah tujuan pembentukan tenaga ahli untuk memajukan kesejahteraan masyarakat daerah.

b. Berdasarkan teori Freis Ermessen (kebebasan bertindak/diskresi) dan AsasAsas Umum Pemerintahan yang Baik (AUPB)

Menurut perspektif hukum administrasi negara (HAN), Freies Ermessen (diskresionare power) adalah salah satu sarana yang memberikan ruang bergerak bagi pejabat / badan-badan administrasi negara untuk melakukan tindakan tanpa harus terikat sepenuhnya pada UU. Pengaturan secara normatif terkait asas freis ermessen ini terdapat dalam UU No. 30 Tahun 2014 tentang Administrasi Pemerintahan. Dalam beberapa referensi dan literatur, praktik diskresi di Indonesia banyak diperbolehkan, tetapi diberi batasan, yakni pemerintah boleh menggunakan namun batasannya terdiri dari :

1) Apabila terjadi kekosongan hukum (rechtsvacum); 
2) Hanya dilakukan pejabat pemerintahan yang berwenang;

3) Apabila ada kebebasan penafsiran (bebas interpretasi);

4) Apabila ada delegasi perundangundangan;

5) Demi kepentingan umum.

Praktik diskresi atau kebebasan bertindak oleh suatu pejabat menimbulkan dilema, dilema yang dimaksud ialah disatu pihak diskresi selalu digunakan, maka akan terjadi perbuatan pemerintah yang sewenangwenang, namun sebaliknya jika pemerintah takut menggunakan diskresi, maka tujuan pembangunan nasional sulit terwujud. Selanjutnya ialah asas-asas umum pemerintahan yang baik atau disebut AUPB, merupakan landasan pembentukan hukum dalam peyelenggaraan pemerintahan termasuk pemerintahan daerah.

Istilah AUPB berasal dari Terjemahan dari bahasa Belanda "algemene Beginselen van Behoorlijk Bestuur" Behoorlijk arti sebenarnya bukan baik melainkan sebaiknya atau sepatutnya ada juga ahli yang mengatakan layak atau selayaknya. Unsur-unsur behoorlijkheid menurut G.J. Wiarda meliputi lima asas yaitu :

1. Asas fairplay (permainan yang layak);

2. Asas kecermatan;

3. Asas sasaran yang tepat;

4. Asas keseimbangan;

5. Asas kepastian hukum.

Pengaturan secara normatif terkait AUPB terdapat dalam UU No. 30 Tahun 2014. Dalam Pasal 1 angka 17 disebutkan bahwa AUPB adalah prinsip yang digunakan sebagai acuan penggunaan wewenang bagi pejabat pemerintahan dalam mengeluarkan keputusan dan/atau tindakan dalam penyelenggaraan pemerintahan.

Berdasarkan pemaparan di atas, dapat disimpulkan bahwa pejabat yang berwenang dalam hal ini Walikota dapat melakukan tindakan diskresi atau kebebasan bertindak dalam mengatur suatu hal yang tidak ada aturannya, sepanjang hal tersebut tidak bertentangan dengan aturan dan demi kepentingan umum. Landasan atau asas yang menjadi pijakan ialah freis ermessen dan AUPB sebagaimana telah disampaikan dan dianalisis pada bagian sebelumnya. Dengan demikian tindakan diskresi pada pembentukan tenaga ahli walikota telah mendapatkan rujukan dan dukungan argumentasi yuridis yang kuat.

\section{c. Berdasarkan Konsepsi Otonomi Daerah}

Menurut Pasal 1 ayat (6) Undang-Undang Nomor 23 Tahun 2014 tentang Pemerintahan Daerah, menyatakan otonomi daerah adalah hak, wewenang, dan kewajiban daerah otonom untuk mengatur dan mengurus sendiri urusan pemerintahan dan kepentingan masyarakat setempat dalam sistem Negara Kesatuan Republik Indonesia.

Berdasarkan berdasarkan pemaparanpemaparan di atas, pada prinsipnya gagasan untuk membentuk tenaga ahli untuk membantu seorang kepala daerah, dapat dilihat dari berbagai aspek. Hal tersebut dikarenakan tidak ada aturan yang jelas mengatur terkait tenaga ahli bagi kepala daerah (gubernur/walikota/bupati) dalam peraturan perundang-undangan terkait pemerintahan daerah dan perangkat daerah. Perihal yang di atur dalam UU Pemda dan PP Perangkat daerah ialah tenaga ahli untuk DPRD, dan staf ahli untuk membantu tugas gubernur/walikota/bupati, sementara terkait tenaga ahli kepala daerah tidak spesifik disebutkan.

Kemudian, dari beberapa aturan terkait pemda dan perangkat daerah tidak ada larangan dari pemerintah pusat dalam hal ini kementerian dalam negeri. Oleh karena itu, beberapa daerah mengatur terkait tenaga ahli dalam suatu peraturan kepala daerah (perkada). Daerah-daerah tersebut antara lain, kota Yogyakarta, Bantul, dan Jombang. Dalam perpsepktif konsepsi negara kesejahteraan, selama tujuannya untuk mensejahterakan masyarakat, maka negara ikut terlibat aktif dalam urusan masyarakat. Kemudian dari asas diskresi, seorang kepala daerah dapat membuat suatu tindakan atau kebebasan bertindak dalam menjalankan kewenangannya, selama tidak bertentangan dengan aturan hukum yang lebih tinggi, terjadi kekosongan hukum, sesuai dengan AUPB, berdasarkan alasanalasan objektif, demi kepentingan umum dan dilakukan dengan itikad baik.

Pemerintah Daerah memiliki asas otonomi untuk melaksanakan urusan rumah tangganya, hal ini jelas termaktub dalam Pasal 18 (5) UUD NRI Tahun 1945. Sehingga seorang kepala daerah memiliki 
kewenangan untuk membuat suatu kebijakan dalam memajukan daerah dan mensejahterakan masyarakat daerah dengan beberapa gagasannya.

Hal utama yang wajib dilakukan oleh seorang kepala daerah ialah mentaati asas penyelenggaraan daerah yang telah tertuang dalam UU Pemda, yaitu : kepastian hukum, tertib penyelenggaaraan negara, kepentingan umum, keterbukaan, proporsionalitas, akuntabilitas, efisiensi, efektif dan keadilan. Sehingga gagasan terkait pembentukan tenaga ahli walikota tersebut harus tetap mengacu pada asas penyelenggaraan daerah tersebut.

Seorang kepala daerah menurut undangundang yang mengatur tentang pemerintah daerah memiliki kewenangan untuk menetapkan peraturan kepala daerah. Oleh karena itu, jika ingin membentuk tenaga ahli kepala daerah, haruslah diatur secara jelas dalam peraturan kepala daerah tentang tenaga ahli kepala daerah. Hal ini dilakukan sesuai prinsip negara hukum, dimana semua tindakan penguasa haruslah berlandaskan hukum. Seorang kepala daerah mempunyai wewenang untuk diskresi, namun tidak serta merta dilakukan serampangan atau tanpa rencana dan arah yang jelas. Selain itu, seorang walikota wajib mentaati AUPB dalam melakukan suatu tindakan atau membuat suatu kebijakan.

Penjabaran lebih lanjut terkait hasil analisis terhadap beberapa aturan, teori dan praktik penyelenggaraan tenaga ahli kepala daerah dijelaskan sebagai berikut. Pertama, segala tindakan yang dikeluarkan penguasa atau pejabat yang berwenang harus bersandar pada aturan hukum, hal ini merupakan ciri negara hukum, selanjutnya gagasan pembentukan tenaga ahli kepala daerah sebaiknya guna mewujudkan kesejahteraan umum dalam hal ini mensejahterakan masyarakat daerah.

Kedua, landasan yang digunakan dalam pembentukan tenaga ahli ialah asas freis ermessen atau diskresi, yang mana pejabat yang berwenang dalam hal ini kepala daerah mempunyai kebebasan bertindak hal ini dilakukan bertujuan mengisi kekosongan hukum, melancarkan penyelenggaraan pemerintahan dan mengatasi stagnasi pemerintahan dalam keadaan tertentu guna kepentingan umum. Dalam melakukan diskresi tersebut, terdapat beberapa persyaratan yang harus terpenuhi, sehingga tidak dilakukan sembarangan, melainkan sesuai aturan yang berlaku.

Ketiga, menurut konsep otonomi, pemerintah daerah berhak mengatur urusannya sendiri sesuai kerangka NKRI, oleh karena itu, seorang kepala daerah mempunyai gagasan untuk membentuk tenaga ahli guna membantu tugasnya dalam mewujudkan visi dan misi yang telah tertuang dalam RPJMD merupakan kewenangan kepala daerah yang dimiliki.

Keempat, dalam perspektif teori kewenangan, pertanyaan mendasar ialah apakah seorang kepala daerah berwenang membentuk tenaga ahli untuk membantu tugas walikota, mengingat sudah ada staf ahli dalam struktur pemerintahan daerah. Menurut KBBI, kata wewenang disamakan dengan kata kewenangan yang diartikan sebagai hak dan kekuasaan untuk bertindak, kekuasaan membuat keputusan, memerintah melimpahkan tanggungjawab kepada orang/badan lain. Berdasarkan pengertian tersebut, kepala daerah berdasarkan mempunyai kewenangan untuk membuat keputusan. Menurut Bagir Manan, kekuasaan hanya menggambarkan hak untuk berbuat atau tidak berbuat, dalam hukum wewenang berarti hak dan kewajiban. Selanjutnya Ateng Syafruddin menjelaskan terkait kewenangan adalah apa yang disebut kekuasaan formal, kekuasaan yang berasal dan diberikan undang-undang. Sementara Hadjon, mengatakan kewenangan pemerintahan sekurangkurangnya terdiri dari tiga komponen, yang terdiri dari pengaruh, dasar hukum dan konformitas hukum.

Berdasarkan pemaparan pendapat tentang kewenangan menurut para ahli di atas, maka kepala daerah mempunyai wewenang untuk menetapkan peraturan pembentukan tenaga ahli, hal ini dapat dilihat dari sumber kewenangan kepala daerah diperoleh dari Pasal 65 UU No. 23 Tahun 2014 tentang Pemerintah Daerah. Disebutkan dalam pasal tersebut kepala daerah berwenang menetapkan perkada dan keputusan kepala daerah, mengambil tindakan tertentu dalam keadaan mendesak yang sangat dibutuhkan oleh daerah/masyarakat dan melaksanakan wewenang lain sesuai dengan ketentuan peraturan perundang-undangan. 


\section{d. Berdasarkan Praktik Ketatanegaaran di Pemerintah Daerah di Indonesia}

Fakta terkait praktik ketatanegaraan yang diselenggarakan oleh pemerintah daerah terkait tenaga ahli telah terbukti. Hal ini dapat dilihat ada beberapa daerah baik kota maupun kabupaten yang telah menerapkan tenaga ahli bagi kepala daerahnya dan di atur dalam suatu peraturan kepala daerah (peraturan bupati/walikota). Beberapa daerah tersebut yaitu Yogyakarta, Jombang dan Bantul. Bahkan beberapa kemajuan pembangunan di kota tersebut dipengaruhi oleh tenaga ahli yang sesuai bidangnya.

\section{KESIMPULAN}

Pembentukan tenaga ahli untuk membantu seorang kepala daerah, dalam hal ini kepala daerah dalam sistem ketatanegaraan di Indonesia diperbolehkan sepanjang demi kepentingan umum dan mensejahterakan masayrakat daerah serta tidak bertentangan hukum yang lebih itnggi. Mengacu pada pembahasan di atas disampaikan berbagai dukungan yuridis yang terkait dengan landasan konstitusional, peraturan perundangan, landasan teoritik dan konseptual, (negara hukum, welfare state, diskresi, otonomi daerah dan kewenangan), serta praktik ketatanegaraan dalam penyelenggaraan pemerintahan daerah di beberapa daerah di Indonesia. Selain itu, tujuan utamanya adalah untuk mensejahterakan masyarakat, maka negara pada konteks ini pemerintah daerah yang ada di Indonesia harus ikut terlibat aktif dalam urusan masyarakat khususnya dalam mensejahterakan masyarakatnya.

\section{DAFTAR PUSTAKA}

Hasrul, M \& Pradana, S.A. 2017. Urgensi Staf Ahli Kepala Daerah (Kajian Teoritik Keberadaan Staf Ahli sebagai Pembantu Kepala Daerah dalam Penanganan Isuisu Strategis di Daerah. Literasi. Jogjakarta

Peraturan Pemerintah Nomor 18 Tahun 2016 tentang Perangkat Daerah.

Peraturan Walikota Yogyakarta Nomor 2 Tahun 2018 tentang Tenaga Ahli Walikota Yogyakarta.

Peraturan Bupati Jombang Nomor 31 Tahun 2018 tentang Tenaga Ahli Bupati Jombang.

Peraturan Bupati Nomor 25 Tahun 2016 tentang Pedoman Pengangkatan Dan Pemberhentian Tenaga Ahli Bupati.

Undang-Undang Dasar Negara Republik Indonesia Tahun 1945.

Undang-Undang Nomor 7 Tahun 2014 tentang MPR, DPR, DPD dan DPRD.

Undang-Undang Nomor 23 Tahun2014 tentang Pemerintahan Daerah.

Undang-Undang Nomor 30 Tahun 2014 tentang Administrasi Pemerintahan. 
2 Jurnal Pamator 